\title{
ИЗАЗОВИ ИНФОРМАЦИОНО-КОМУНИКАЦИОНИХ ТЕХНОЛОГИЈА И УЛОГА ОБРАЗОВАҢА У ПРЕВЕНЦИЈИ ДИГИТАЛНОГ НАСИљА ${ }^{3}$
}

Сажетак: У раду се полази од Гиденсовог теоријског концепта глобализације да она из корена мења начин на који појединац размишља о себи и о свом односу са другим људима, као и личне животе кроз безличне изворе - медије, интернет и популарну културу. Развој информационо-комуникационих технологија допринео је глобалном повезивању људи и интензивној комуникацији, али и повећању ризика и опасности од насиља у виртуелном простору. Иако правне норме санкционишу дигитално насиље, оно је све заступљеније, а његове последице се рефлектују како на појединца, тако и на друштво у целини. Стога убрзани развој дигиталних технологија захтева ефикаснију заштиту деце и младих од ризика и опасности које им прете у виртуелном простору. У раду се елаборирају неке социјалне импликације коришћења информационо-комуникационих технологија, разматра се проблем дигиталног насиља и указује се на улогу образовања у области безбедног коришћења дигиталних технологија (интернета, мобилних телефона), при чему се наглашава кључни значај израде и примене активне васпитно-образовне стратегије.

Кључне речи: глобализација, информационо-комуникационе технологије, дигитално насиље, активна васпитно-образовна стратегија, хуманистичко образовање.

\section{Увод}

Услед повећања броја корисника информационо-комуникационих технологија и све разноврснијег садржаја на интернету, последњих година се интензивно воде дебате о сложеним социјалним импликацијама коришћења ових

\footnotetext{
${ }^{1}$ lela.milosevic.radulovic@filfak.ni.ac.rs

${ }^{2}$ suzana.markovic.krstic@filfak.ni.ac.rs

${ }^{3}$ Рад у оквиру пројекта Традиција, модернизација и национални идентитети у Србији и на Балкану у процесу европских интеграција 179074Д (потпројекат Традиционално и модерно у систему образовања у Србији и на Балкану у процесу евроинтеграција), који реализује Центар за социолошка истраживања Филозофског факултета у Нишу, а финансира Министарство просвете, науке и технолошког развоја РС.

Рад саопштен на међународној научној конференцији Традиција, модернизација и идентитети IX: Улога универзитетске заједнице у унапређењу регионалног развоја и афирмацији културе мира на Балкану, која је одржана на Филозофском факултету у Нишу 25. маја 2018. године.
} 
технологија. Комуникација путем дигиталних технологија пружа нова искуства, проширује видике и могућности за стицање нових знања, чини информације доступним великом броју људи, али истовремено прети да радикално промени људске односе, као и да маргинализује оне којима је дигитални свет недоступан. Интернет омогућава превазилажење граница времена и простора стварајући „умрежено друштво“ (Castells). Појављује се као нови домен друштвености у коме човек није увек сигуран одакле му прети опасност и коме да се супротстави. „Наши лични животи су неизбежно претрпели измене од када су силе глобализације продрле у локалне контексте, наше домове и заједнице, и то кроз безличне изворе - медије, интернет и популарну културу. [...] Глобализација из корена мења начин на који размишљамо о себи самима и о свом односу са другим људима“"(Gidens 2003: 66).

У времену у коме се сукобљавају многе вредности, савремени начин живота праћен је бројним „произведеним ризицима“ (Beck), а „простор токова и безвременско време“ (Castells) постају материјалне основе нове културе. Глобални развој нових информационо-комуникационих технологија мења нашу културу - с једне стране омогућава повезивање са читавим светом, а с друге стране, радикално трансформише простор и време, који чине темељне димензије људског живота. Развој информационо-комуникационих технологија допринео је глобалном повезивању људи и интензивној комуникацији, али, поред бројних предности, носи са собом и потенцијалне ризике, међу којима је и ризик од дигиталног насиља. Дигитална технологија поткрепљује нову реалност, а нова, паралелна, виртуелна реалност отвара простор за злоупотребе на интерперсоналном нивоу јер анонимност доприноси ослобађању од социјалних ограничења.

У таквим околностима потребно је развијати културу мира и толеранције, образовати и припремати децу и младе за живот у заједници. Социјализација у духу културе мира омогућава прогресивно мењање појединаца и њихових основних навика у сазнајном, културном и вредносном смислу (Sakan 2013: 24). Образовање има пресудну улогу када је реч о усвајању и развијању хуманистичких вредности. „Општепризнато је да су знања незаменљив фактор социјалног и хуманистичког развоја и неопходна компонента уједињења и оплемењивања грађана. Она су способна да пруже човеку неопходне податке у његовом супротстављању изазовима новог миленијума, разумевање јединства вредности и припадања општем социјалном и културном простору“ (Жуков 2008: 6). Због тога је важно да знање буде целовито и комплексно и да доприноси хуманизацији и међуљудском разумевању.

3. Гудовић поставља питање „да ли је могуће градити просперитетно друштво ако се визија образовања сведе на успешно предузимање друштвених улога и механичко инкорпорирање појединца у друштво, а истовремено запостави стварање свести или савести младих бића“ (2011: 249-250). Сходно томе, од наставника се очекује да преузму неке нове улоге, међу којима је употреба информационо-комуникационих технологија, познавање њених предности и ризика и ангажовање у погледу развијања безбедносне културе у 
школи. Недовољно развијена безбедносна култура, односно неопрезно поступање са новим технологијама могу их учинити извором бројних и различитих опасности, јер се виртуелни простор не може потпуно друштвено контролисати. Због тога је неопходно васпитање и образовање деце и младих за сигурно бивствовање у виртуелном простору - како препознати ризике, шта учинити када прети опасност од насиља, какву одговорност појединац има када користи нове технологије и какве су последице за оне који крше правила.

Како проблеми злостављања у виртуелном простору производе негативне последице које се рефлектују не само на угроженог појединца, већ и на његово окружење и породицу, као и на друштво у целини, у научним круговима се покрећу иницијативе за истраживање овог значајног друштвеног проблема у циљу подизања свести о опасностима које прете (нарочито код деце и младих) и израде превентивних стратегија. Подизање свести, израда превентивних стратегија и правовремено и успешно деловање у правцу ненасилног решавања проблема подразумева активно учешће свих чланова универзитетске заједнице од универзитетских професора, преко студената, до стручних тимова основних и средњих школа који примењују у пракси стечена знања на универзитетима. Универзитетски наставници имају водећу улогу у осмишљавању и конципирању нових студијских програма у којима би значајно место требало да припада предметима чији се наставни садржаји базирају на истраживањима и знањима о ненасиљу, толеранцији, култури мира, али и о врстама насиља, а посебно дигиталном, које преузима примат у свету захваћеном процесом глобализације, као и могућностима превентивног деловања у овој сфери друштвеног живота. У том смислу, неопходно је да сви чланови универзитетске заједнице интензивирају своје активности, најпре у сфери стицања знања о могућностима превентивног деловања и адекватном васпитању и образовању деце и младих, а потом у сфери решавања конкретних проблема са којима се деца и млади сусрећу у непосредном окружењу, широј друштвеној заједници и виртуелном простору.

Предмет овог рада је разматрање улоге образовања у превенцији дигиталног насиља у контексту развоја информационо-комуникационих технологија. Стога су у раду најпре изложени теоријски приступи о дигиталном насиљу и социјални чиниоци који утичу на појаву дигиталног насиља, а затим су презентовани резултати неких емпиријских истраживања појавних облика и учесталости дигиталног насиља над децом основношколског и младима средњошколског узраста. Циљ рада је да укаже на значајну улогу наставника и стручних високо образованих кадрова (стручних тимова школе) у превенцији дигиталног насиља и на потребу интензивирања васпитно-образовног (превентивног) деловања школе.

\section{Дигитално насиље код деце и младих}

Насиље као непожељан облик понашања прожима све сегменте друштва и све је присутније међу децом и младим људима. Постоје различити ставови у вези са појавом и ширењем насиља у школи - с једне стране, сматра се да је 
насиље у школи у порасту, а са друге, да је једнако присутно као и пре, али да је сада социјално видљивије, јер појединачни инциденти задобијају већу медијску пажњу. С обзиром на то да статистика иде у прилог првој тврдњи, улажу се велики напори како би се пронашла адекватна решења за сузбијање насиља.

Постоје различити облици насиља: физичко, психичко (емоционално), социјално, дигитално, сексуално насиље, занемаривање, злоупотреба и експлоатација. Сви облици насиља међусобно се преплићу, тако да између њих не постоје јасне границе. У последње време, поред осталих облика насиља, посебну пажњу јавности и стручњака заокупља дигитално насиље. O дигиталном насиљу (енг. cyberbullying) je реч када се дигитална технологија (интернет и мобилни телефони) користи у циљу повређивања и узнемиравања других особа. У литератути се налазе и други термини за овај облик насиља, нпр. електронско насиље, online насиље, cyber насиље и слично. Дигитално насиље се испољава на различите начине: слање порука путем мобилног телефона или интернета, односно комуникацијска активност сyber технологијом која се манифестује у виду злонамерних и претећих текстуалних или видео порука, фотографија или позива. Реч је о случајевима када неко користи дигиталне уређаје како би се лажно представљао или како би претио другима (узнемиравање, снимање мобилним телефоном или камером и јавно постављање снимака). Починиоци или жртве овог насиља могу бити и појединци и читаве групе. Најчешће је присутно код деце и младих, али је заступљено и међу одраслима. Примери дигиталног насиља су бројни: претње, ругање и задиркивање, ширење гласина и лажи о некоме, слање неприкладних садржаја, крађа идентитета и тако даље. Отежавајуће околности за контролисање овог облика насиља су што се садржај веома једноставно може поделити са другима и што га може за кратко време видети велики број људи. Деца веома често злоупотребљавају интернет навођењем лажних података о узрасту. То потврђује и истраживање које је спроведено крајем 2012. године (Popadić i Kuzmanović 2013). Резултати овог истраживања показали су да чак половина анкетираних десетогодишњака има профил на некој социјалној мрежи (углавном на Фејсбуку) навођењем лажних података о свом узрасту. У том смислу, дигитално насиље може да буде опасније од насиља које се дешава у реалном свету управо због анонимности извршиоца (мањи страх од откривања и кажњавања), а може да се врши у било које време и са било ког места.

Неке од специфичности дигиталног насиља у односу на традиционалне облике насиља су: висок степен анонимности насилника, стална доступност жртве, широка, практично неограничена публика и трајност учињеног, при чему анонимност охрабрује насилнике, а појачава несигурност код жртве. Путем дигиталних уређаја насилници могу приступити жртви у било које време и са било ког места, тако да жртва може постати стална мета виктимизације (Popadić i Kuzmanović 2013: 17). Насилник може лажно да се представља, да вређа, оговара и клевеће, узнемирава и прогања или да заведе малолетника/ малолетницу. Такође може да шаље електронску пошту са туђег налога претварајући се да је корисник налога, да вређа друге са којима је власник налога у 
контакту и може свима да прослеђује његове приватне поруке и фотографије. Оговарање и клеветање представља слање или постављање неистинитих информација о другој особи с намером угрожавања њене репутације, а узнемиравање слање увредљивих, провокативних и грубих порука. Узнемиравање се може вршити како путем персоналних рачунара, тако и путем мобилних телефона, када се шаље већи број текстуалних порука од стране једног или више удружених насилника у циљу прогањања друге особе.

У овом раду користи се израз дигитално насиље. Оно укључује било какав облик вишеструко сланих порука путем интернета или мобилног телефона, а које имају за циљ да повреде, узнемире или на било који други начин оштете децу, младе или одрасле који се не могу заштити од таквих поступака (Pregrad i sar. 2008: 361).

У Закону о основама система образовања и васпитања $(2017$, чл. 111) насиље, злостављање и занемаривање су изричито забрањени, при чему се забрана јасно и недвосмислено наглашава, а насиље, злостављање и занемаривање прецизно одређују и дефинишу. Под насиљем и злостављањем подразумева се сваки облик једанпут учињеног, односно понављаног вербалног или невербалног понашања које има за последицу стварно или потенцијално угрожавање здравља, развоја и достојанства личности детета, ученика и одраслог, док се под дигиталним насиљем и злостављањем подразумева злоупотреба информационо-комуникационих технологија која може да има за последицу повреду друге личности и угрожавање достојанства, а остварује се слањем порука електронском поштом, смс-ом, ммс-ом, путем веб-сајта (website), четовањем, укључивањем у форуме, социјалне мреже и другим облицима дигиталне комуникације. Овим законом се такође обавезује и установа да одмах поднесе пријаву надлежном органу уколико дође до насиља, злостављања или занемаривања.

Стога ауторке полазе од претпоставке да препознавање проблема насиља у школи, његових облика, димензија и актера, као и сагледавање детерминанти које утичу на његову појаву у васпитно-образовним установама може значајно допринети адекватној друштвеној реакцији у школи и ван ње, у складу са законским одредбама, а у циљу решавања овог значајног друштвеног проблема.

\section{Социјални чиниоци дигиталног насиља код деце и младих}

Социјални чиниоци дигиталног насиља су предмет истраживања бројних научника. Ж. Спалевић наводи да је један од разлога насиља у виртуелном простору жеља и потреба за успостављањем моћи над другима, досада или жеља за забавом, јер је понижавање и вређање других један од начина забаве и разоноде којим неке особе могу ојачати свој его. Разлог може бити и одговор на насиље насиљем (Spalević 2013: 723), као и задовољавање патолошких сексуалних потреба. Доступност нових технологија у одсуству моралне и друштвене одговорности појединаца доприноси повећању ризичног понашања приликом њихове употребе. Постоје бројни чиниоци који утичу на појаву насиља 
код деце и младих (насиља над другим). Аналитичка психологија упућује на темперамент личности, педагогија на значај и улогу васпитања, а социологија указује на утицаје друштвене средине.

Резултати истраживања мишљења наставника о узроцима агресивног понашања ученика у школама (Savović 2002: 268) показују да три четвртине наставника обухваћених истраживањем сматра да је општа криза у друштву узрок агресивног понашања, а нешто мањи број да су родитељи агресивних ученика одговорни за њихово понашање, као и мас-медији који приказују непримерене садржаје. Међутим, има и наставника који истичу утицај школе на понашање ученика и који сматрају да им је неопходна стручна помоћ како би се успешно суочили са проблемом агресивног понашања својих ученика.

Факторе који су од значаја за насилничко понашање деце и младих могуће је класификовати на: 1) срединске факторе (локација школе, близина делинквентних група), 2) факторе који се тичу саме школе (велики број ученика у школи, начин органзовања надзора током паузе), 3) породична „клима” (величина породице и структура породице, социоекономски статус, неслагање и насиље, васпитни стил родитеља, 4) статус и особине ученика (нови ученик у школи, научени агресивни обрасци понашања, непријатељски однос према околини). Када је реч о факторима који се тичу саме школе, нека истраживања (The School Survey on Crime and Safety 2003 ) показују да је у 90\% школа, које имају више од 1.000 ученика, било насилничких инцидената, за разлику од мањих школа, до 300 ученика, код којих је насилничко понашање забележено у $60 \%$ школа. Осим броја ученика, важан чинилац насилничког понашања ученика у школи је и организација њихових активности, а посебно организовање надзора ученика током школског одмора. „Школска клима“ коју карактеришу често супростављање, нетолерантност и сукоби на различитим релацијама, између ученика и наставника и самих ученика, такође може да подстиче насиље као облик ,„решавања проблема“ у школској средини.

Велики је број фактора који доприносе појави насиља у школи, али се могу идентификовати неки основни: 1) масовност популације ученика (већи број ученика - већа могућност да се они или њихова имовина угрозе); 2) просторна концентрисаност популације ученика (много ученика на малом простору); 3 ) старост ученика (зависност облика и интезитета насиља од узраста ученика); 4) већа подложност ученика манипулацијама (наивност и лаковерност као последица недовољног општег знања и недостатка животног искуства); 5) физичка инфериорност ученика (лакше је повредити ученика него одрасло лице); 6) поткултура ученика (имитирање вршњака); 7) имовина ученика (скупа гардероба, накит, мобилни телефони, велики џепарци, доприносе да ученик постане мета крађе старијих ученика или других лица); 8) имовина школе (ТВ, камере, видео-бимови, рачунари); 9) неразвијеност механизама за старање о безбедности у школи (недостатак електронске опреме за надгледање школе) (Mijalković 2004, нав. према Stajić i sar. 2006: 161). У зависности од специфичности социокултурне средине у којој се школа налази (сеоске средине, мањи градови, развијеност криминала и сличне околности) наведени фактори су различито заступљени. 
Када је реч о породици, указује се на везу између типа породице и појаве насилничког понашања код деце. Наиме, према истраживању Б. Скабернеа, чак у 40\% случајева, малолетни делинквенти потичу из непотпуних породица (Flere 1976: 111). Он указује на појаву идентификације с агресором изван породице као на механизам који доводи до делинквентног понашања и то у случајевима када није била могућа позитивна развојна идентификација у породици. Осим тога, недостатак љубави или агресивно понашање родитеља у кажњавању може утицати на прихватање насилничког понашања од стране њихове деце као облика решавања проблема у односу на друге људе у њиховом окружењу. Неки аутори истичу најчешће грешке и објективне недостатке у процесу васпитања и социјализације: неуједначеност понашања родитеља (благо/строго), безобзирно и престрого кажњавање, низак културни ниво родитеља који су се преселили у развијенију средину, занемаривање деце од стране родитеља (Jašović, Bergant i sar. 1970). Индивидуалне карактеристике појединца (физичке, психолошке и интелектуалне) такође битно утичу на начин његовог реаговања на подстицаје друштвене средине. Наиме, појединац који има негативан доживљај света око себе имаће непријатељски однос према околини, за разлику од појединца са позитивним односом према свету који ће се пријатељски односити према другим људима.

Резултати истраживања показују да се неке личне особине, као и неке карактеристике социјалног контекста, чешће доводе у везу с изложеношћу дигиталном насиљу (Кузмановић и сар. 2016: 25), а то су: 1) узраст - старији ученици су чешће изложени дигиталном насиљу; 2) род - девојчице су чешће од дечака изложене дигиталном насиљу и чешће су сведоци дигиталног насиља; 3) школски успех - ученици који имају ниже оцене у школи чешће трпе дигитално насиље; 4) недовољно развијене социјалне вештине младих доводе се у везу са чешћом изложеношћу дигиталном насиљу; 5) учесталост коришћења технологије - млади који чешће користе интернет, чешће су изложени дигиталном насиљу; 6) склоност ризичном понашању на интернету - млади који су склонији ризичном понашању на интернету (остављају личне податке на блоговима, форумима, игрицама), чешће су изложени дигиталном насиљу; 7) укљученост у класично насиље - млади који су чешће изложени класичним облицима насиља, чешће су и жртве дигиталног насиља.

Други концентрични круг утицаја на појаву насилничког понашања деце и омладине (а посебно дигиталног насиља) може се разматрати у склопу тзв. породичних чинилаца, односно породичне климе. Велики значај за појаву насилничког понашања уопште, а и дигиталног, има структура породице, социјални статус и образовни ниво родитеља, насилничко понашање родитеља, недостаци у социјализацији и васпитању деце у породици, као и васпитно занемаривање деце. Позитивна породична клима у којој њени чланови отворено комуницирају, размењују искуства и разматрају проблеме са којима се срећу у ванпородичном окружењу могу значајно да допринесу правилној социјализацији која подстиче развијање социјалних вештина деце и младих у духу ненасилних социјалних односа, толеранције и сарадње са другим људима. 
Трећи концентрични круг утицаја на појаву насилничког понашања везује се за чиниоце у оквиру школске средине. Овој групи чинилаца припада: просторна концентрација ученика (бројност), опремљеност школе (посебно рачунарима, видео-бимовима и слично), доступност информационо-комуникационих технологија ученицима, развијеност механизама за старање о безбедности у школи (камере, електронска опрема за праћење ученика), особине наставника, компетентност наставника у информатичко-комуникационој сфери, интензивна комуникација на релацији ученик-наставник, наставник-ученик, наставник-особље школе, ученик-особље школе, комуникација и сарадња наставника са друштвеним институцијама и представницима локалне и шире друштвене средине, као и укљученост школе у пројекте који су усмерени на развијање позитивне школске климе.

Негативне последице дигиталног насиља се вишедимензионално рефлектују како на угроженог појединца као корисника нових технологија, тако и на породично, школско и ваншколско окружење, али и на друштво у целини. Стога се о разноврсности облика и све већој учесталости дигиталног насиља међу децом и омладином све чешће јавно говори и наглашава потреба његовог истраживања, уз ангажовање великог броја стручњака из различитих научних области, како би се пронашли путеви за адекватну друштвену реакцију (превенцију, кажњавање и ресоцијализацију).

\section{Ранија истраживања дигиталног насиља}

Дигитално насиље је веома често предмет научних истраживања у свету, а последњих година се овај проблем интензивније истражује и у нашој земљи. Истраживање учесталости и последица дигиталног насиља спроведено на узорку од 5000 испитаника студентске популације у Јужној Кореји показало је да је чак $36 \%$ студената било жртва дигиталног насиља током 2012. године. Они су се због тога осећали усамљено, беспомоћно и мање вредно. Норвешки истраживачи спровели су истраживање на узорку од 4700 испитаника и утврдили да психичко насиље анонимним смс порукама нарочито негативно утиче на девојчице. Према извештају, једна девојчица је због тих застрашујућих порука доживела ноћне море које су је толико прогањале да је помишљала на самоубиство. Њена вршњакиња је, уместо рођенданских честитки, примила 25 пакосних смс порука које су је толико потресле да се више није усудила да иде у школу и била јој је неопходна психо-терапија (Stanić 2007, нав. према Škrlec i sar. 2010: 666).

Када је реч о доступности информационо-комуникационих технологија као фактору ризика, резултати истраживања потврђују да су деца која имају мобилне телефоне више изложена опасностима од педофила. У Јапану где су телефони с интернетом и камером доступнији, забележено је $260 \%$ повећања сексуалног злостављања деце и преноса дечје порнографије путем мобилних телефона. Поред тога, у 90\% истражених случајева сексуалног злостављања 
први је контакт успостављен путем мобилног телефона (Lee 2005, нав. према Škrlec i sar. 2010: 666).

Једно од значајних истраживања дигиталног насиља у нашој земљи спроведено је крајем 2012. године, у организацији Министарства просвете, науке и технолошког развоја, УНИЦЕФ-а и компаније Теленор, у оквиру пројекта Зауставимо дигитално насиље. У фокусу овог истраживања било је коришћење дигиталне технологије и ризици приликом коришћења ове технологије међу ученицима основне и средње школе у Србији. У истраживању је учествовало 3786 ученика (2272 из основне и 1514 из средње школе), 3078 родитеља и 1379 наставника. Резултати истраживања су показали да је од ризичних понашања код ученика основне и средње школе најзаступљеније прихватање захтева за пријатељство на бројним социјалним мрежама од особа са којима се никада нису срели у реалном животу. Такође је ризична и комуникација путем чета са потпуно непознатим особама, а нарочито је алармантно то што су многи спремни и да открију своје личне податке непознатим особама (опширније: Popadić i Kuzmanović 2013).

Резултати истраживања потврђују да је незавидна улога школе и наставника у решавању проблема дигиталног насиља, с обзиром на то да је најмањи број ученика проблем „поделило“ са наставницима или са стручним тимом школе (1\%). Разлози за овакво „стање“ у школском окружењу могу се тражити у недостатку поверења и комуникације на релацији ученик-наставно и ненаставно особље школе, стиду што су баш они „жртве“, страху од јавности и кажњавања, страху од претњи насилника. У том смислу, неопходна је брза реакција стручњака у овој области у виду спровођења адекватних мера и акција.

Последице дигиталног насиља могу бити и озбиљније од оних у реалним ситуацијама, јер је публика много шира, а снага писане речи је већа од изговорене увреде. Појединци различито реагују на насиље - неки не придају посебан значај томе, док други врло емотивно доживљавају све што им се догађа. Последица таквог емотивног шока може бити промена понашања - повлачење у себе, занемаривање обавеза, преиспитивање значаја пријатељства, породице и школе. Посебно је забрињавајућа појава што такве особе и саме могу да постану насилне или равнодушне према насиљу. У прилог овој тврдњи иду бројни видео снимци на интернету (које после преносе и остали електронски медији, углавном телевизије) о томе како појединци снимају мобилним телефонима туче, злостављања и малтретирања других, уместо да потраже помоћ и покушају да спрече насиље.

Истраживање дигиталног насиља реализовано је и у Чачку 2015. године (Реšić 2015) на узорку од 98 ученика осмог разреда из две основне школе. Истраживано је колико ученици користе дигиталне технологије, да ли се излажу ризицима дигиталне комуникације, у ком степену су укључени у различите облике дигиталног насиља, као и како су реаговали уколико им се тако нешто догодило. Препоруке ученицима, наставницима и родитељима о томе на који начин спречити дигитално насиље саставни су део рада и важан су корак у заједничком деловању свих актера на превенцији дигиталног насиља. 
Истраживачки налази показали су да већина анкетираних ученика свакодневно или скоро свакоденевно користи интернет, било преко мобилног телефона било преко рачунара и да најчешће посећују социјалне мреже, гледају спотове, филмове и серије, док интернет веома ретко користе за читање и писање блогова и посећивање форума. Већина ученика има профил на социјалној мрежи који редовно користи и изложени су узнемиравању. У таквим ситуацијама, најпре се обраћају другу, другарици, брату или сестри. Најчешћи ризици коришћења дигиталне технологије су прихватање позива за пријатељство од особа које не познају у реалном свету, четовање са њима и остављање личних података. Посебно је значајан податак да половина анкетираних ученика не зна да блокира особу од које не жели да прима електронску пошту. Такође је значајно да се ученици о ризицима на интернету информишу путем интернета, а да о томе најчешће разговарају са родитељима, што показује недовољну улогу наставника, односно школе у развијању безбедносне културе. Овакви резултати потврђују да је веома важна едукација родитеља о ризицима приликом коришћења дигиталних технологија. Значајно је навести и резултате да велики број корисника интернета није заинтересован за област безбедности. Тенденција пораста броја корисника на интернету указује на потребу предузимања превентивних мера у циљу спречавања злоупотреба. Поред примарне улоге родитеља у томе, неопходно је и укључивање наставника, односно друштва у целини у циљу подизања свести јавности о ризицима и опасностима (Реšić 2015: 4-5).

Проблем дигиталног насиља истраживан је и у две основне школе у југоисточној Србији (у општини Ниш и општини Гаџин Хан), на узорку од 200 ученика (Marković Krstić i Milošević Radulović 2014: 525-546). Испитивани су појавни облици и учесталост дигиталног насиља код ученика основне школе и улога васпитања и образовања у његовој превенцији. Истраживачки налази који се односе на информисаност ученика о опасностима приликом коришћења информационо-комуникационих технологија показују да их на ризике и опасности најчешће упозоравају родитељи, дупло ређе наставници, док их стручни тимови упозоравају шест пута ређе од родитеља. Значајни истраживачки налази су да су их родитељи највише упозоравали на опасности које се тичу психофизичког здравља приликом коришћења компјутера и мобилних телефона. То се може схватити као резултат родитељске бриге за здравље своје деце, али и као њихово недовољно познавање других опасности које су повезане са коришћењем дигиталних технологија. Управо због тога је неопходно веће ангажовање наставника и чланова стручних тимова школе (психолога, педагога, социолога, социјалних радника) на овом пољу васпитно-образовног деловања. Важан истраживачки налаз је да су ученици сеоске школе (општина Гаџин Хан) која нема стручни тим школе (има само психолога), у већој мери изложени дигиталном насиљу, а у мањој мери упознати с опасностима приликом коришћења нових технологија у односу на ученике градске школе (општина Ниш) у којој стручни тим ради у пуном саставу, што потврђује значај ангажовања стручних тимова у школама (опширније: Marković Krstić i Milošević Radulović 2014: 545). 
Компарација резултата бројних истраживања није могућа, јер постоје значајне разлике у коришћеним инструментима. Да би поређења била смислена неопходно је подударање инструмената и језичких формулација. У раду је дат приказ резултата међународног истраживања из 2015. године Деца света на интернету (Global Kids Online), које је реализовано је у Аргентини, Јужној Африци, на Филипинима и у Србији, у организацији УНИЦЕФ истраживачке канцеларије - Innocenti и LSE (London School of Economics and Political Science). Истраживана су права и могућности деце и младих на интернету (ученици и ученице од 9 до 17 година), као и ризици и последице дигиталне комуникације. Велики изазов за истраживачке тимове у овим земљама био је да развију методологију која би била довољно стандардизована да омогући међународно поређење резултата, а да буде довољно флексибилна да узме у обзир локалне и контекстуалне варијације. Истраживачки налази за Аргентину су национално репрезентативни, а они који се односе на Србију, Јужну Африку и Филипине потичу из пилот истраживања и треба их тумачити с опрезом.

Најпре је испитано да ли су и у којој мери деца у контакту са људима са којима су се упознала путем интернета и да ли се састају са њима. Истраживачки налази су показали да су нарочито дечаци у контакту са непознатим људима на мрежи - на Филипинима $24 \%$ и више од половине дечака у Србији (52\%). У Аргентини, Србији и на Филипинима већина деце се не сусреће лицем у лице са људима које упознају на мрежи, док је половина испитане јужноафричке деце то чинила. Деца су наводила и интернет преваре, затим рекламе које су биле порнографске, непријатне или страшне вести или слике, узнемиравање или сексуално узнемиравање од стране непознатих особа и људи који деле превише личних информација на интернету. Колико често су деца узнемиравана од стране других варира од земље до земље - највише је у Србији 36\% и у Јужној Африци 22\%. У свим земљама су старија деца чешће узнемиравана него млађа.

Ради испитивања нежељеног сексуалног искуства повезаног с интернетом и мобилним технологијама деци су постављана питања о томе да ли су у протеклих годину дана видели неке слике са сексуалним садржајем на мрежи, колико често се то дешавало и какве су њихове емоционалне реакције на такве слике. Резултати истраживања показују да је слике са сексуалним садржајем током протекле године примило између 12\% и 22\% деце у четири земље. Изјаве неке деце су гласиле: „Питали су ме за сексуалне информације о себи или како изгледа моје тело без одеће“; ,Замољен сам да говорим о сексу са неким на интернету иако то нисам желео“; „Неко на интернету ме је замолио да урадим нешто сексуално када нисам желео“ и слично. Слична искуства пријавила су и деца на Филипинима: „Он (пријатељ) ми је рекао да разговарам са странцима, јер понекад имате среће да разговарате са женском особом, а ако разговарате са мушкарцем послаће вам новац и ствари уколико се претварате да сте жена“ (дечак од 15-17 година). Међутим, у анкети на Филипинима велики проценат деце није одговорио на ово питање, што указује и на њихову неспремност да разговарају о „осетљивим“ темама.

Испитивана је и реакција деце, односно да ли су тражила помоћ последњи пут када их је нешто узнемирило на интернету. У све четири земље најчешћи 
извор подршке су пријатељи - између једне трећине и две трећине деце је разговарало са пријатељем последњи пут када се нешто догодило на интернету. Следећи извор подршке су родитељи, а као разлог због чега се не би поверила родитељима деца наводе страх од тога како ће они реаговати. Према одговорима деце, мање од трећине родитеља има честе разговоре са својом децом о томе како да буду безбедни на интернету, а најмање трећина (и скоро две трећине у Јужној Африци) никада или готово никада то не чини. Квалитативно истраживање је показало да деца често мисле да имају боље дигиталне вештине од својих родитеља и да им често помажу да се укључе у друштвене мреже.

Иако су резултати истраживања показали да мали број деце разговара са својим наставницима о стварима које им сметају или их узнемиравају (мање од 10\% у свим земљама), наставници су значајан ресурс за децу и имају потенцијално важну улогу у подржавању активности деце на интернету. Међутим, истраживање у фокус групама је показало да деца сматрају да садржај курикулума понекад заостаје за њиховом дигиталним компетенцијама. На пример, девојчица од 16 година наводи: „Недавно смо имали предавање о безбедности на интернету. Било је смешно колико ствари нису споменули, неке стварно застрашујуће ствари. А многе ствари су биле прикривене као да нису застрашујуће, вероватно нису хтели да нас уплаше (фокус група у Србији, девојчице од 14 до 17 година). У Јужној Африци на питање да ли питају свог наставника за помоћ девојчице наводе: „Они мене питају“; „Они увек нас питају“ (фокус група у Јужној Африци, девојчице од 14 до 17 година). Истраживачи закључују да дубља анализа може показати који фактори доприносе овим празнинама и која су деца изложена већој опасности јер се суочавају с двоструким недостатком да имају мање дигиталних вештина и да им се нуди мања подршка (опширније Byrne et al. 2016: 56-75).

На основу добијених резултата истраживања, аутори закључују да се стратешке политике морају усмерити на потребе и права деце у дигиталном добу. Социјалне мреже су најчешћа платформа путем које деца шаљу и примају узнемиравајуће поруке. С једне стране социјалне мреже су прилика за већину деце да комуницирају и изразе себе, а са друге стране оне за њих представљају опасност, јер могу бити повређени.

Интересантно је да је у Србији, Јужној Африци и на Филипинима већина деце сматрала да је интернет веома користан, иако је око једне трећине искусило нешто узнемиравајуће на интернету у протеклих годину дана. У Аргентини је већина деце изјавила да постоје проблеми на интернету. Поставље се питање да ли у Аргентини заиста има више проблема или су више сензибилисани за online ризике или се сусрећу са више проблема јер чешће раде на интернету итд. То указује да су потребна даља истраживања како би се испитали фактори који подржавају рањивост или отпорност деце у различитим контекстима. Приликом планирања стратешких политика значајан је узраст/старост. У Јужној Африци, на пример, и посебно на Филипинима, млађа деца мање користе интернет и имају мање дигиталних вештина него деца у Србији (или у Аргентини). Сва четири тима из земаља укључених у истраживање изјавила су да су 
најефикасније стратегије за промовисање сигурности деце на интернету оне које укључују ангажман родитеља и наставника, али и развијање одговорности саме деце. Школе и наставници имају значајну улогу у развијању дигиталне писмености и промовисање сигурног и одговорног коришћења интернета. С обзиром на то да се деца најпре обраћају својим пријатељима када су у невољи, веома је важна едукација вршњака (опширније Byrne et al. 2016: 76-89). Укључивањем и других земаља у овај пројекат могу се проширити искуства и тако помоћи креаторима политика за безбедно коришћење интернета.

С обзиром на то да се облици и учесталост дигиталног насиља умножавају, а његове последице по психофизички развој и социјални живот деце и младих људи добијају алармантне димензије, неопходна је хитна друштвена интервенција у овој сфери. Посебну улогу у превентивном (васпитно-образовном) деловању би требало да имају наставници и стручни тимови школе, у складу са њиховим педагошким и стручним компетенцијама.

\section{Улога наставника и стручних тимова школе у превенцији дигиталног насиља}

За превенцију насиља у школи користе се мере које повећавају идентификацију ученика, наставника и родитеља са школом (ученичко веће, ученичке новине, ваннаставне активности, школски савет, билтен за родитеље, посебне активности за запослене) и мере које се спроводе са циљем да науче децу и младе да конфликте решавају без насиља (тренинг из социјалног учења, тренинг из вршњачког лидерства, школски социјални рад). Од посебног значаја је креирање школске климе у којој се учи, развија и негује култура међусобног поштовања и уважавања личности. У том смислу, неопходно је да се преко одговарајућих садржаја у наставним програмима утиче на формирање моралних ставова ученика, али и да се ученици упознају са важећим правним нормама и санкцијама (правна социјализација личности). Образовни програми треба да садрже чињенице из области права и да допринесу понашању у складу са правним нормама у оквирима саме школске институције, као и ван ње. На тај начин ученик се у школи упознаје са својим грађанским правима и обавезама, развија одговорност пред собом и социјалним окружењем за сопствене поступке и деловања и способност усклађивања сопственог деловања са постојећим законодавством.

Убрзани развој дигиталних технологија захтева ефикаснију заштиту деце од ризика и опасности које им прете у виртуелном простору у коме проводе доста времена. Правна регулатива у области заштите деце од злоупотреба путем интернета обухвата Конвенцију о правима детета из 1989. године и Устав Републике Србије (опширније о правној регулативи: С̆ović 2014: 380-385), али упркос томе насиље је годинама уназад веома заступљено.

Емпиријски налази потврђују да је улога наставника (Марковић Крстић 2006: 191-213) и стручних тимова школе у превенцији дигиталног насиља од 
изузетног значаја, тако да се намеће питање њихових стручних компетенција и могућности за васпитно-образовно деловање у овој сфери друштвеног живота. С друге стране, резултати истраживања показују да готово сви наставници сматрају да је дужност школе да подучава ученике како да се заштите од дигиталног насиља (Popadić i Kuzmanović 2013). Међутим, скоро половина анкетираних наставника сматра да је недовољно информисана о дигиталном насиљу, а две трећине наставника сматра да школа нема довољно капацитета да се суочи с овим озбиљним проблемом. То значи да је за превенцију дигиталног насиља неопходна дигитална писменост наставника, односно обука наставника о томе како да припреме своје ученике да на правилан начин користе дигиталне технологије и, наравно, развијање социјалних вештина и развијање свести о ненасилној комуникацији, како у реалном, тако и у виртуелном свету. Иако данас постоји велики број дефиниција дигиталне писмености, заједничко им је да укључују како техничка знања и вештине, тако и критичко и креативно коришћење информација, решавање проблема у дигиталном окружењу, као и безбедно коришћење информационо-комуникационих технологија. Дигитална писменост је данас темељна животна вештина, која, с једне стране, омогућава човеку да се реализује у бројним животним улогама, док, с друге стране, маргинализује оне који не умеју да приступе свету дигиталних информација.

Тачно је да данас деца и млади људи у великом проценту користе дигиталне технологије и да се технички веома добро сналазе, али уколико се дигитална писменост процењује на основу сложенијих когнитивних вештина, као што је поређење неких информација и критички приступ поузданости сајтова, добија се потпуно другачија слика од очекиване, а то је да дигиталне вештине младих нису на задовољавајућем нивоу, односно да младе људе без обзира на учестало коришћење дигиталних технологија не можемо сматрати и дигитално писменим (Calvani et al. 2012, нав. према Кузмановић и сар. 2016: 34).

Стратегија развоја образовања у Србији до 2020. године препознаје значај и улогу дигиталних технологија за унапређивање образовног система. У складу с тим као и са „Смерницама за унапређивање улоге информационо-комуникационих технологија у образовању“, који је Национални просветни савет усвојио у децембру 2013. године, Министарство просвете, науке и технолошког развоја Републике Србије објавило је Оквир дигиталних компетенција - Наставник за дигитално доба. Дигиталне компетенције наставника су веома значајне, а под њима се подразумева скуп знања, вештина, ставова, способности и стратегија неопходних за квалитетно коришћење информационо-комуникационих технологија (Ferrari 2012, нав. према: Okvir digitalnih kompetencija 2017: 5).

Компетенције наставника у области безбедног коришћења информационо-комуникационих технологија, омогућавају правовремено препознавање проблема насиља у школској и ваншколској средини и сагледавање детерминанти које утичу на појаву његових различитих облика, тако да могу значајно допринети адекватној друштвеној интервенцији, а посебно интензивирању превентивног деловања. Компетентни наставници свесни су чињенице да ди- 
гитално насиље може имати трајне последице на ментално здравље ученика, социјализацију и квалитет међуљудских односа. Због тога је нужна сарадња породице, школе (наставника, стручних тимова) и друштва у целини у свестраном сагледавању ове проблематике, како би се, коришћењем позитивних искустава других актера, могле предузети одговарајуће превентивне активности.

Превентивне активности доприносе подизању нивоа свести и осетљивости за препознавање насиља и дефинисање мера за заштиту од насиља. У оквиру превентивних активности веома је важно објаснити ученицима како да се заштите у ситуацијама када путем интернета наиђу на узнемирујући садржај или непримерене понуде. Ради физичке безбедности неопходно је упозорити ученике да никада не остављају личне податке на интернету, не означавају своје кретање на интернету, не снимају своје шифре на јавном компјутеру, не договарају виђање преко интернета са непознатима и да се увек одјаве са свог налога. Психичка безбедност може се остварити упозоравањем ученика да уколико наиђу на неприкладан и непријатан садржај одмах затворе интернет претраживач и обавесте неког старијег о томе, да не сплеткаре преко интернета, јер интерна шала може да буде доступна свима и да на тај начин многи буду повређени. Такође је важно да схвате да не сносе кривицу уколико добију поруке узнемиравајућег садржаја и постану жртве дигиталног насиља, већ да насиље пријаве. Комуникација на релацији родитељи-школа је веома важна јер наставници и стручни тим школе могу да упозоре родитеље уколико дође до промене у понашању ученика како би се на време реаговало (опширније: Marković Krstić i Milošević Radulović 2014: 542-545). Један од инструмената који се користи превенције насиља у нашој земљи је Посебни протокол за заштиту деце и ученика од насиља, злостављања и занемаривањ а у образовно-васпитним установама, који садржи систем индикатора за идентификовање појава које потенцијално могу да доведу до насиља (опширније: Kalezić-Vignjević i sar. 2007).

Васпитање и образовање за социјалну одговорност представља полазну основу за спречавање насилничког понашања, а интензивирање васпитно-образовног (превентивног) деловања школе, наставника и стручних тимова, једна је од могућих стратегија за решавање овог значајног друштвеног проблема (нпр. уређивање посебних интернет страница на сајту школе о дигиталном насиљу, израда школских паноа са тематиком дигиталног насиља, гледање филмова о дигиталном насиљу, организовање разговора са вршњацима, стручним тимом школе, родитељима и представницима МУП-а о дигиталном насиљу, осмишљавање неких активности поводом Дана безбедног интернета, који се иначе обележава сваке године, другог уторка у фебруару у преко сто земаља).

Превенцију дигиталног насиља је важно спроводити на свим нивоима, почевши од појединца преко породице, школе (при чему велику улогу имају чланови стручног тима школе - психолог, педагог, социолог, социјални радник, затим наставници и директор школе), других институција и друштва у целини. И поред интензивног коришћења дигиталне технологије не може се очекивати да ће данашња деца и млади људи постати дигитално писмени без подршке формалног образовања. 
Корени дигиталног насиља у Србији могу се тражити у социјалним, економским, технолошким променама, као и у убрзаном развоју информационокомуникационих технологија које су све доступније младима. Убрзани развој нових технологија допринео је глобалном повезивању и интензивној комуникацији, али и повећању ризика и опасности у виртуелном свету комуникације. Економска и социјална трансформација, „катастрофална друштвена дешавања“ (Mihailović 2004) посебно погађају омладину, коју такође карактеришу прелази (транзиције) - млади људи пролазе кроз период сазревања и припремања за преузимање трајних друштвених улога. Поклапање друштвене транзиције са природним омладинским транзицијама доводи до противуречности у социјализацији и до ризичних понашања. Доба економске и друштвене транзиције карактеришу специфични друштвени проблеми, који дају свој печат васпитно-образовном процесу у школи и понашању младих људи. Потенцирање на вредностима потрошачког друштва, с једне стране, и велики број незапослених и социјално угрожених лица, с друге стране, утичу на моралну деградацију и учесталост социјалних аномалија.

Последњих година се у научним круговима и стручним дебатама све више говори о сложеним социјалним импликацијама коришћења информационо-комуникационих технологија и механизмима заштите од могућих негативних последица. Резултати емпиријских истраживања дигиталног насиља указују на то да се испољава у различитим облицима и различитим интензитетом, а да су ученици основних школа највише изложени опасностима, како због учесталог коришћења информационо-комуникационих технологија, тако и због недовољне припремљености и недостатка знања да се на адекватан начин заштите од могућег негативног утицаја. Стога се јасно осликава потреба већег васпитнообразовног ангажовања наставника и стручних тимова у школама у којима су оформљени и њиховог неодложног конституисања у школама у којима још увек не постоје, ради успешнијег превентивног деловања у сфери безбедног коришћења дигиталних технологија.

Васпитно-образовно деловање школе (наставника и стручних тимова школе) у области безбедног коришћења дигиталних технологија (интернета, мобилних телефона) подразумева целину активности у школском и ваншколском окружењу у виду конципирања, конституисања и примене активне васпитно-образовне стратегије. Она обухвата низ активности од стране компетентних наставника и стручњака у школском и ваншколском окружењу - од упознавања ученика и родитеља с опасностима које се могу јавити приликом коришћења дигиталне технологије и давања упутстава како да се оне избегну (уређивање посебних страница на сајту школе са садржајима о безбедности на интернету и дигиталном насиљу; упознавање са дигиталним насиљем кроз текстове у школским часописима; израда школских паноа; гледање спотова/филмова о дигиталном насиљу, уз обавезан разговор након тога; организовање разгово- 
ра, вршњачких обука, трибина и радионица, позивање представника МУП-а у школу да говоре о безбедности на интернету) преко пружања стручне помоћи у стицању неопходних знања из информатике (коришћење компјутерских програма за блокирање и филтрирање нежељених порука; саветовање ученика да не одговарају на провокативне и увредљиве поруке; помоћ ученицима у прекидању „ланца“" насиља и саветовање ученика да промене број мобилног телефона и адресу електронске поште; саветовање ученика да сачувају информације важне за истрагу и пријаве насиље полицији), до евалуације ефеката превентивних мера (облици и учесталост насиља након спровођења мера).

Без обзира на то што дигитално насиље није искључиво повезано са школским окружењем и што многи сматрају да није задатак школе да се бави проблемом дигиталног насиља, неоспорно је да наставници и стручни тимови школе имају изузетно значајну улогу, како образовну тако и васпитну, у превенцији и решавању проблема дигиталног насиља. То, између осталог, потврђују и поменути Закон о основама система образовања и васпитања и Посебан протокол за заштиту деие и ученика од насиља, злостављања и занемаривања у образовно-васпитним установама, који су обавезујућег карактера за све васпитне-образовне установе, а у којима је наглашена и прописана кључна улога школе (наставника и стручних тимова) када је реч о заштити ученика од свих облика насиља.

Дакле, успешан модел за решавање проблема дигиталног насиља би био континуирана сарадња на релацији ученик - родитељ - наставник - психолог - педагог - социолог - директор школе. Васпитање и образовање за социјалну одговорност од кључног је значаја за спречавање насилничког понашања, а интензивирање превентивног васпитно-образовног деловања школе, наставника и стручних тимова, једна је од неопходних стратегија за решавање овог актуелног друштвеног проблема.

\section{Литература}

Byrne, J., Kardefelt-Winther, D., Livingstone, S. and M. Stoilova. (2016) Global Kids online. Research synthesis 2015-2016. https:/www.unicef-irc.org/publications/pdf/ IRR_2016_01.pdf (pristup sajtu: jul 2019).

Gidens, E. (2003) Sociologija. Beograd: Ekonomski fakultet.

Гудовић, 3. (2011) „Социјални аспекти и врсте инкомпатибилности образовног система према друштвеној пракси“. Нова српска политичка мисао, посебно издање, бр. 2: 247-262.

Жуков, В. (2008) Универзитетско образовање. Београд: Српска академија образовања.

Zakon o osnovama sistema obrazovanja i vaspitanja. „Službeni glasnik RS“, br. 88/2017.

Jašović, B. i sar. (1970) Porodica i socijalizacija mladih. Beograd: Savet za vaspitanje i zaštitu mladih. 
Kalezić-Vignjević, A. i sar. (2007) Posebni protokol za zaštitu dece i učenika od nasilja, zlostavljanja $i$ zanemarivanja u obrazovno-vaspitnim ustanovama. Beograd: Ministarstvo prosvete RS.

Кузмановић, Д. и сар. (2016) Дигитално насиље - превеничја и реаговағе. Београд: Министарство просвете, науке и технолошког развоја РС и Педагошко друштво Србије.

Marković Krstić, S, i L. Milošević Radulović. (2014) „Vaspitanje i obrazovanje u funkciji bezbednog korišćenja novih tehnologija u procesu globalizacije“, u Savremene paradigme u nauci i naučnoj fantastici, Nauka i savremeni univerzitet 3 (ur. B. Dimitrijević ur.), 525-546. Niš: Filozofski fakultet Univerziteta u Nišu.

Марковић Крстић, С. (2006) „Елементи друштвеног угледа наставника“, Годишњак за социилогију. Ниш: Филозофски факултет Универзитета у Нишу, 2 (2), 2006: 191-213.

Mihailović, S. (2004) „Oduzimanje budućnosti. Omladina Srbije u vodama tranzicije“, u Mladi zagubljeni u tranziciji (M. Nikolić i S. Mihailović ur.), 17-37. Beograd: Centar za proučavanje alternativa.

Okvir digitalnih kompetencija - Nastavnik za digitalno doba. Beograd: Ministarstvo prosvete, nauke i tehnološkog razvoja (uz podršku British council) http://www. mpn.gov.rs/wp-content/uploads/2017/04/Okvir-digitalnih-kompetencija-Final-1.pdf (pristup sajtu: decembar 2017).

Pešić, A. (2015) Obrazovanje kao prevencija elektronskom nasilju. http://www.ftn.kg.ac. rs/download/SIR/SIR\%20Andrijana\%20Pesic.pdf (pristup sajtu: decembar 2017).

Popadić, D. i D. Kuzmanović. (2013) Korišćenje digitalne tehnologije, rizici i zastupljenost digitalnog nasilja među učenicima u Srbiji. Beograd: Ministarstvo prosvete, nauke i tehnološkog razvoja RS, UNICEF, Telenor.

Pregrad, J. i sar. (2008) Predstavljanje kampanje „Prekini lanac!“ - prevencija elektroničkog zlostavljanja. Nasilje nad djecom i među djecom, 359-367. Osijek: Filozofski fakultet.

Sakan, M. (2013) „Revitalizacija kulture mira“. Svarog, časopis za društvene i prirodne nauke, br. 7. Banja Luka: Nezavisni univerzitet.

Savović, B. (2002) „Disciplinski problemi u osnovnoj i srednjoj školi: mišljenje nastavnika", Zbornik 34 Instituta za pedagoška istraživanja. Beograd: Institut za pedagoška istraživanja.

Spalević, Ž. (2013) Karakterizacija psihološkog zlostavljanja u Cyber prostoru, http:// www.infoteh.rs.ba/zbornik/2013/radovi/RSS-3/RSS-3-9.pdf (pristup sajtu: decembar 2013).

Stajić, Lj, S. Mijalković i S. Stanarević. (2006) Bezbedonosna kultura mladih. Kako živeti bezbedno. Beograd: Draganić.

The School Survey on Crime and Safety (2003) (http://nces.ed.gov/surveys/ssocs/ (pristup sajtu: maj 2009. godine).

Flere, S. (1976) Obrazovanje u društvu. Niš: Gradina.

Čović, A. (2014) „Načini zloupotrebe dece putem interneta“. Internet $i$ društvo, pr. D. Todorović i sar, str. 379-393. Niš/Beograd: Srpsko sociološko društvo, Beograd; Filozofski fakultet u Nišu; Institut za uporedno pravo, Beograd. 
Škrlec, N. i sar. (2010) „Nasilje modernim oblicima komunikacije - mobitel - prikaz slučaja“, u Nasilje nad djecom i među djecom (V. Kolesarić ur.), 665-670. Osijek: Filozofski fakultet.

\title{
CHALLENGES OF INFORMATION-COMMUNICATION TECHNOLOGIES AND THE ROLE OF THE EDUCATION IN THE PREVENTION OF DIGITAL VIOLENCE
}

\begin{abstract}
The paper starts from Giddens' theoretical concept of globalization which radically changes the way in which an individual thinks about himself and about his relationship with other people, as well as personal lives through impersonal sources - the media, the internet and popular culture. The development of informationcommunication technologies has contributed to the global connection of people and intensive communication, as well as to the increase of the risk and danger of violence in the virtual space. Despite the existence of legal regulations that sanction digital violence, it is increasingly present, and its consequences are reflected on the individual and the society as a whole. Therefore, the accelerated development of digital technologies requires more effective protection of children and young people from the risks and threats that lurk in the virtual space. The paper elaborates some social implications of the use of information-communication technologies and the problem of digital violence and points to the role of education in the field of safe use of digital technologies (the Internet, mobile phones) emphasizing the key importance of designing and implementing an active educational strategy.
\end{abstract}

Key words: Globalization, Information-communication technologies, Digital violence, Active educational strategy, Humanistic education 
